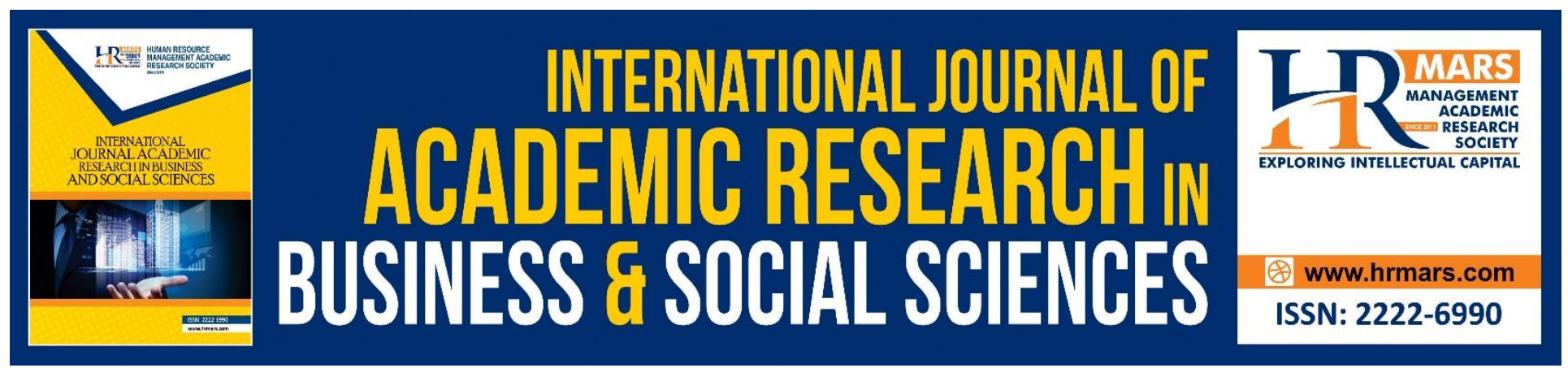

\title{
Quality of Food and Tourists' Satisfaction of Penang Delicacies in Predicting Tourists' Revisit Intention
}

Y. Atikahambar, A. Zainal, M. Rahayu, Rahayu Mokhtar

To Link this Article: http://dx.doi.org/10.6007/IJARBSS/v8-i12/5262

DOI: $10.6007 /$ IJARBSS/v8-i12/5262

Received: 14 Nov 2018, Revised: 13 Dec 2018, Accepted: 15 Dec 2018

Published Online: 06 Jan 2019

In-Text Citation: (Atikahambar, Zainal, Rahayu, \& Mokhtar, 2018)

To Cite this Article: Atikahambar, Y., Zainal, A., Rahayu, M., \& Mokhtar, R. (2018). Quality of Food and Tourists' Satisfaction of Penang Delicacies in Predicting Tourists' Revisit Intention. International Journal of Academic Research in Business and Social Sciences, 8(12), 1606-1618.

Copyright: (C) 2018 The Author(s)

Published by Human Resource Management Academic Research Society (www.hrmars.com)

This article is published under the Creative Commons Attribution (CC BY 4.0) license. Anyone may reproduce, distribute, translate and create derivative works of this article (for both commercial and non-commercial purposes), subject to full attribution to the original publication and authors. The full terms of this license may be seen at: http://creativecommons.org/licences/by/4.0/legalcode

Vol. 8, No. 12, 2018, Pg. 1606 - 1618

http://hrmars.com/index.php/pages/detail/IJARBSS

JOURNAL HOMEPAGE

Full Terms \& Conditions of access and use can be found at http://hrmars.com/index.php/pages/detail/publication-ethics 


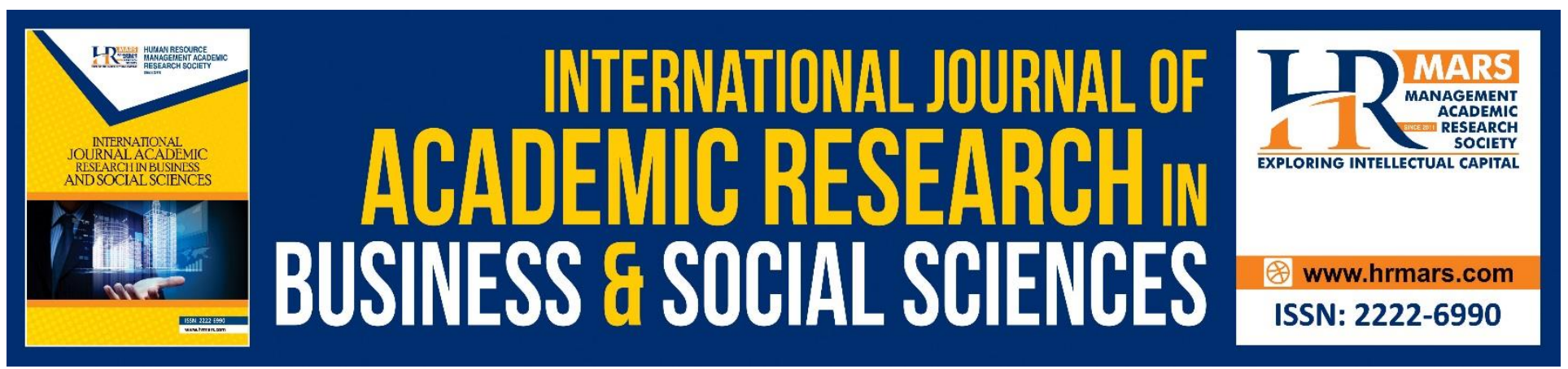

\title{
Quality of Food and Tourists' Satisfaction of Penang Delicacies in Predicting Tourists' Revisit Intention
}

\author{
Y. Atikahambar ${ }^{1}$, A. Zainal2 ${ }^{2}$ M. Rahayu ${ }^{3}$, Rahayu Mokhtar ${ }^{3}$ \\ ${ }^{1}$ Kulliyyah Hospitality and Creative Arts, Universiti Islam Antarabangsa Sultan Abdul Halim Muadzam \\ Shah (UniSHAMS), Malaysia. \\ ${ }^{2}$ Faculty of Hotel and Tourism Management, Universiti Teknologi MARA Puncak Alam (UiTM), \\ Malaysia. \\ ${ }^{3}$ Selayang Community Colleges, Malaysia.
}

\begin{abstract}
Penang foods become one of the attractions for the foreign tourists to visit Penang. This study focuses on the relationship between quality and tourists' satisfaction of Penang delicacies and revisit intention among foreign tourists. $82 \%$ response rate or a total of 328 questionnaires were completed by international tourists who visited Penang Island. The results revealed a positive relationship between quality, tourists' satisfaction and revisit intention $\left(\mathrm{R}^{2}=0.32, \mathrm{~F}\right.$ Change $\left.=68.35, \mathrm{p}<0.01^{* *}\right)$. This study contributes to the literature on the relationship between quality, satisfaction and revisit intention. From the practical perspectives, Penang Tourism Board and local authorities could use this finding as a means of enhancing the quality of Penang foods, hence attracting more tourists to visit this paradise island. Furthermore, business organizations and marketers could spend more resources on advertising Penang food, culture and ethnic events and community interactions. This study will also provide food managers more information on food quality, thus understanding international customer needs and wants.
\end{abstract}

Keywords: Quality, Satisfaction, Revisit Intention, Penang Food

\section{INTRODUCTION}

In 2017, Malaysia received a total of 25,948,459 international tourists and recorded a $0.1 \%$ growth in tourist receipts, thus contributing RM82.2 billion to the country's revenue (Tourism Malaysia, 2017). Tourism has been an important source of revenue and a catalyst for Penang's economic growth for a number of years. Placed as the second highest sector after manufacturing, tourism accounted for more than 30 percent of the state's Gross Domestic Product (GDP) in 2012 (Mok, 2013). As one of Malaysia's leading tourist destinations, after Kuala Lumpur and Pahang (The Star Online, 2012), in 2013, the total number arriving in Penang reached a record of 4.70 million (Tourism Malaysia, 2015). 
Notably, there are many attractions with regards to cultural and tourism such as landscape, building and food heritage that can boost the tourism industry.

According to the statistics from Malaysia Immigration Department, Penang has seen a growing number of international arrivals flying via Penang International Airport which grew at an annual growth rate of $7 \%$. In 2014 , it increased by $6.9 \%$ total up to 718,000 visitors from 671,000 visitors recorded in 2013 (Penang Tourism Survey, 2016). Penang which is known as Pearl of the Orient is one of the most visited destinations in Malaysia and got listed as one of the top states visited by foreign tourists. Additionally, Penang Tourists Survey in 2016 affirmed Penang was visited for a variety of reasons with top essential activities such as experiencing local food, shopping, sightseeing, and visiting historical sites (Tourism Malaysia, 2017).

Penang is a prominent destination for food lovers or culinary tourists and it is known as food heaven among Penangites and tourists. It offers masses of tastes from different cultures and ethnicity, as it is recognized as one of the famous street food of the world combining Malay, Chinese, Indian, Arabic, Siamese, and European cuisines, as a real feast. British daily The Independent reported that Penang was listed as the top culinary spot for 2014 by Lonely Planet (The Star,2014). Conversely, James Oseland a world renowned food writer, magazine editor, and reality cooking show judge has claimed Penang as the world's best food destination T. Ruxyn (2016). He noted despite the fact that the environment of Penang has undergone major changes, but the quality of the food are still maintained due to the competition between other eateries to serve the best food.

In dealing with types of tourism, among other states, Tourism Malaysia categorised Penang into cultural tourism, adventure, beach, medical tourism and agriculture tourism, food tourism and many more. Thus, in offering international visitors many different experiences, the local cuisines should become apparent, obvious and visible as a destination's intangible heritage; as experiencing the delectable taste allow tourists to gain an authentic cultural experience (Zainal et al., 2010). As a tourism initiative to brand Malaysia as a food heaven, the Ministry of Tourism have encouraged states to transpire unique food trails that are state, region, and even community specific. This allows tourists to savour different local delicacies and gain inimitable and unique cultural experience (Zainal et al., 2010; Jalis et al., 2014).

Hence, this present study focuses on relationships between food quality, satisfactions, and revisit intention from the perspective of international tourists. It offers significant knowledge and understanding to the tourism board, local authorities as well as food operators in Penang on the impact of the quality of Penang foods on tourists. The hypotheses formulated are as follows:

H1: Quality of food is significantly related to tourists' satisfaction

$\mathrm{H} 2$ : Quality of food is significantly related to tourists' revisit intention.

H3: Tourists' satisfaction mediates the relationship between quality of food and revisit intention. 


\section{LITERATURE REVIEWS}

In Malaysia, tourism industry has become the most important industry that contributed to the foreign exchange (Economic Planning Unit (EPU), 2015). In 2014, the industry generated RM72 billion of foreign exchange and RM379 million of revenue. There are several attractions for tourists to visit this country such as culture, heritage, and food, and previous study showed that food tourism grew tremendously and became one of the interesting areas in the current tourism industry (Zainal et al., 2014).

Despite of indulging taste buds, study indicated that food tourism impacted the tourist satisfaction and revisit intention (Hendijani, 2016). Revisit intention was highlighted as an important research topic in the competitive market of tourism destinations and tourism scholars also concentrated on repeat visitation as an antecedent of destination loyalty. Past studies acknowledged that many tourist destinations rely seriously on repeat visitors (Jayaraman et al., 2010). In this case, previous researches examined factors influencing tourist behaviour towards a repeat visitation. Food tourism specifically is considered a major event, attraction, and climax experience that could inspire people to travel to their destination and encourage them to repeat visits (Allan, 2016). Repeat visitors often think of food quality (Cho et al., 2014) since food became the important item for the tourist experience and increase their intention to revisit (Jayaraman et al., 2010). Notably, the motivation of food tourism is to obtain special experience and familiarity of authentic cuisines from different ethnicity.

\section{Food Tourism}

Food Tourism grew considerably and became one of the most dynamic and creative segments of tourism. Hence, it contributed to the development of the destination and the region, as well as providing an opportunity for intercultural insight. It was highlighted that food and drink is one of the important elements which tourists had to consume when they travel, and if it is a new experience, probably the sensory experience may be enjoyable and gratifying (Zainal et al., 2014). Researchers noted that food tourism is fast becoming one of the most popular and interesting areas in the tourism industry today (Kim et al., 2011).

Previous studies identified how food tourism has increased and become the most active segment in tourism (Meladze, 2016). The availability of multicultural food (Mohamad \& Som, 2010), (Chang, 2013) could increase tourists intention to visit a place and revisit decision attributes when food is taken into consideration (Rajasenan et al., 2012). Henceforth, local cuisines will be able to add value to the traditional tourism experience, particularly for those tourists who are seeking new experiences (UNWTO, 2017). Accordingly, Penang is the best example that had successfully promoted food tourism in Malaysia. This state is popular with varieties of well-liked food such as nasi kandar (historically Indian Muslims used to carry buckets of rice on a long pole over their shoulders), assam laksa, char kway teow and others. Despite of the popularity of these foods, the food provider should understand the importance of quality of foods that they offer.

\section{Quality}

Previous study noted that quality and perceived value were cognitive responses to the service experience. Gastronomy could add value to tourists' experiences and is associated with quality 
tourism for travelers in search of new products and experiences that yield a high level of satisfaction (Atikahambar et al., (2014).

Food quality is the quality characteristics of food that is acceptable to consumers (Kapiris, 2012). Therefore, to ensure the food tourism is significant among tourists, the food operators and local authorities need to ensure the quality of food is superb. Previous study revealed that food quality is considered as the main product of restaurants and restaurant managers should focus on food quality in order to satisfy customers and keep their values on the long term (Canny, 2014). Predominantly food quality has a positive and significant relationship with customer behavioral intentions in both upscale and quick-service restaurants (Bujisic et al., 2014).

Food quality and other quality dimensions are antecedents and consequences of image in relation with experience. Studies revealed that food quality had positive influence on restaurant image (Ryu et al., 2012), whilst return visitors often think of the food quality (Cho et al., 2014). In addition, the impact of food quality on customer's satisfaction and other influences on food quality and customer's mindset satisfaction found that food quality is predictor of customer perceived values (Ryu et al., 2012).

The food quality attributes allowed restaurateurs to make improvements in areas that could lead to a greater satisfactory to customers' restaurant experience which could also satisfy diners with the quality of its core value such as freshness, menu variety, presentation, temperature, healthy and tastefulness (Rozekhi et al., 2016).

\section{Tourist Satisfaction}

Li et al., (2011), defined satisfaction as "an affective state that is the emotional reaction to a service experience." Past studies reported that food quality directed positive effect on customer satisfaction (Canny, 2014; Nasir et al., 2011). Similarly with other industries, tourists' satisfaction is considered as vital goal for tourism industry (Hendijani, 2016). Meanwhile, (Quach, 2016) described satisfaction as something that is indispensable in determining a successful marketing strategy, whereby "it impacts the choice, the consumption of goods and services, and the decision to return."

Additionally, the most significant aspect in the field of business is customer satisfaction because satisfied customers have significant impact on the profits of business (Sabir et al., 2014).

\section{Revisit Intention}

Revisit intention refers to customers who have previous experiences with the restaurants that they perceive as highly valuable in terms of efficient and economical aspects which will be more likely result into revisit intentions ( $\mathrm{Ha} \&$ Jang, 2010). The effect of destination attributes on revisit intention in Penang, found repeat visitation as an indicator of loyalty in tourist destination that is strongly affected by destination attributes (Mostafavi et al., 2010). Furthermore, several studies found that the destination experience would affect tourists' future visits. Revisit intention had been discussed 
INTERNATIONAL JOURNAL OF ACADEMIC RESEARCH IN BUSINESS AND SOCIAL SCIENCES

Vol. 8, No. 12, Dec, 2018, E-ISSN: $2222-6990$ C 2018 HRMARS

in numerous researches related to food and restaurants and the result indicated that it is imperative for restaurant revenue (Majid et al., 2016; Namin, 2017; Pham et al., 2016b).

\section{The Relationship between Quality, Tourists' Satisfaction and Revisit Intention}

Wang \& Chen (2012), found that the full service restaurant operators desired to obtain favourable behavioral intentions by providing better service space, waiting experience and food quality, thus increasing customer perceptions of overall service quality and value. Previous studies highlighted that food quality had a significant positive effect on customer satisfaction. Greater support was reported in previous studies (Al-Tit, 2015; Nasir et al., 2014), which confirmed food quality as one of the key drivers of customer satisfaction. This is in line with Gagic et al., (2013) that found food quality was a key contributor to customer satisfaction and behavioral intention. This is also supported by studies that focused on perceived quality leading to positive impact to customer revisit intention (Namin, 2017; Pham et al., 2016a).

According to Abdelhamied (2011), customer satisfaction could reflect the customer intention to repatronage in future. Similarly, Zabkar et al., (2010) explored complex relationship between main constructs and behavioral intentions and found that destination attributes affected perceived quality which then affected satisfaction the latter led to revisit intention.

Previous research (Kim et al., 2011) pointed out there was a positive tendency for tourists to revisit the destination and recommend to others once they are satisfied with a destination.

\section{METHODOLOGY}

As the intention of this study is to tap the foreign tourists' opinions on food tourism, Penang was chosen since it had been well documented with variety of popular delicacies. A total of 328 out of 400 questionnaires were returned with a response rate of approximately $82 \%$.

The survey instrument consisted of four sections including the demographic information, food quality (4 items), tourist satisfaction ( 3 items) and revisit intention (4 items). The instruments of quality and satisfaction were adapted from previous studies (Atikahambar et al., 2014; Zainal et al., 2014), based on the works modified from Petrick, (2002) and Oliver's, (1997). The scale ranged from "totally satisfied" (5) to "totally dissatisfied" (1). While tourist's revisit intention was measured ranged from 5 (extremely sure to revisit) to 1 (will not revisit). The instruments were adapted from (Zainal et al., 2014).

\section{RESULTS}

\section{Respondents Characteristics Analysis}

Respondents consisted of $55.5 \%(n=182)$ males and $44.5 \%(n=146)$ females with a majority of respondents aged between 18 and 27 years old (41.5\%). 35.4\% of the respondents were professionals and $42.7 \%$ of the respondents were degree holders. A large number of respondents had visited Penang Island more than 7 times (41.5\%) and the nationality includes Australian, Americans, Asians and Europeans. 
INTERNATIONAL JOURNAL OF ACADEMIC RESEARCH IN BUSINESS AND SOCIAL SCIENCES Vol. 8, No. 12, Dec, 2018, E-ISSN: 2222-6990 @ 2018 HRMARS

\section{Descriptive Analysis for Quality of Food, Tourists' Satisfaction and Revisit Intention}

Descriptive statistics were employed to look at the mean scores to investigate the influence of quality of food toward tourists' satisfaction and revisit intention. The mean scores for all four items in the quality variable ranged from 3.74 to 4.13 thus indicated all items had moderate scores. The probable reasons for these moderate scores were due to the respondents' feelings that the quality of food in Penang Island was inconsistent. Although having the same name, a particular dish may vary in taste and appearance when presented to tourists for the second time.

Meanwhile, the mean scores for all three items for tourists' satisfaction ranged from 4.07 to 4.21 indicated all items with high scores. This indicated that overall the respondents were satisfied with the food and dining experience that they had in Penang Island although the quality of food was unpredictable.

There are four items in the measures on revisit intention that recorded fairly high mean scores ranged from 4.02 to 4.10 . It could be expected that due to positive responses on tourist's satisfaction. It confirmed that respondents would recommend and mention positive things about food in Penang Island to others. Besides that, the potential respondents would return for the food experience in Penang Island given the fact that Penang Island has delectable food. This indicated that there was a close relationship or connectivity between tourist's satisfaction and revisit intention.

Table 1: Descriptive Analysis for Quality of Food, Tourists' Satisfaction and Revisit Intention

\begin{tabular}{|c|l|c|c|}
\hline No & \multicolumn{1}{|c|}{ Item } & \multicolumn{1}{|c|}{$\begin{array}{c}\text { Mean (M) } \\
\text { Std. } \\
\text { Deviation(SD) }\end{array}$} & 0.64 \\
\hline 1 & The quality of the food is outstanding. & 3.84 & 0.60 \\
\hline 2 & The quality of the food is very reliable & 3.82 & 0.69 \\
\hline 3 & The quality of food is very dependable. & 3.71 & 0.69 \\
\hline 4 & The quality of food is very consistent. & 4.21 & 0.70 \\
\hline 5 & $\begin{array}{l}\text { I think I made the correct decision to visit Penang Island for food } \\
\text { experience. }\end{array}$ & 4.07 & 0.70 \\
\hline 6 & $\begin{array}{l}\text { My choice to experience dining different kind of food in Penang Island was } \\
\text { a wise choice. }\end{array}$ & 4.12 & 0.65 \\
\hline 7 & Overall, I am satisfied with the food experience in Penang Island. & 4.09 \\
\hline 9 & I am likely to revisit Penang Island for the good food and friendly people & 4.02 & 0.68 \\
\hline 10 & If I choose to attend an event in the future, I will be sure to come back to & 43 \\
\hline 11 & I would say positive things about food in Penang Island to others & 4.10 & 0.71 \\
\hline
\end{tabular}

\section{Hypotheses Testing}

The relationships between quality, satisfaction and revisit intention were tested using regression analysis as indicated in table 2, 3 and 4. Analyses conducted on the data suggested that quality accounted $28 \%$ of the variance in the tourists' satisfaction $\left(R^{2}=0.28, F\right.$ Change $\left.=131.78, p<0.01^{* *}\right)$ with $(\beta=0.53)$, thus $\mathrm{H} 1$ is supported. Meanwhile quality accounted $18 \%$ of the variance in the tourists' revisit intention $\left(R^{2}=18 \%, F\right.$ Change $\left.=74.51, p<0.05^{*}\right)$, with $(\beta=0.43)$, hence, $H 2$ is supported. 
As a final point, the results of the mediation tests on the relationship between quality, tourists' satisfaction and revisit intention was indicated in table 4. The analysis in Model 1 (quality with revisit intention) revealed that quality accounted $43 \%$ of the variance on revisit intention $\left(R^{2}=0.18, F\right.$ Change=74.51, $\mathrm{p}<0.01^{* *}$ ). Meanwhile, Model 2 (tourists' satisfaction mediates the relationship between quality and revisit intention) revealed $19 \%$ presence of tourists' satisfaction mediates the relationship between quality and revisit intention $\left(R^{2}=0.32, F\right.$ Change $\left.=68.35, p<0.01^{* *}\right)$. The results indicated that tourists' satisfaction partially mediates the relationship between quality and revisit intention. Thus, hypothesis H3 was partially supported.

Table 2: Regression analysis for quality of food and tourists' satisfaction (H1)

\begin{tabular}{ccc}
\hline $\begin{array}{c}\text { Independent } \\
\text { variable }\end{array}$ & Std. $\boldsymbol{\beta}$ & Results \\
\hline Quality & 0.53 & Supported \\
\hline R2 & 0.28 & \\
Adj. R2 & 0.28 & \\
F-Change & 131.78 & \\
\hline
\end{tabular}

Table 3: Regression analysis for quality of food and tourists' revisit intention (H2)

\begin{tabular}{ccc}
\hline Independent variable & Std. $\boldsymbol{\beta}$ & Results \\
\hline Quality & 0.43 & Supported \\
\hline R2 & 0.18 & \\
Adj. R2 & 0.18 & \\
F-Change & 74.51 & \\
\hline
\end{tabular}

Table 4: Regression analysis on the relationship between quality, tourists' satisfaction and revisit intention (H3)

\begin{tabular}{|c|c|c|c|c|}
\hline Hypotheses & $\begin{array}{c}\text { Model } 1 \\
\text { Std. } \beta\end{array}$ & Results & $\begin{array}{c}\text { Model } 2 \\
\text { Std. } \beta\end{array}$ & Results \\
\hline $\begin{array}{l}\text { Independent Variables } \\
\text { :Quality }\end{array}$ & $0.43 * *$ & Supported & $0.19 * *$ & Supported \\
\hline $\begin{array}{l}\text { Mediating Variable : } \\
\text { Tourists' satisfaction }\end{array}$ & & & $0.44 * *$ & Supported \\
\hline $\mathrm{R}^{2}$ & 0.18 & & 0.32 & 0.18 \\
\hline Adj. $R^{2}$ & 0.18 & & 0.32 & 0.18 \\
\hline F Change & $74.51 * *$ & & $68.35^{* *}$ & $74.51 * *$ \\
\hline
\end{tabular}

\section{DISCUSSION}

The analyses for quality of food to tourist satisfaction such as outstanding, very reliable and dependable taste are moderate due to the stance that the quality of food in Penang Island is inconsistent based on previous experiences and knowledge that tourists had during their prior visits. 
Nevertheless, there were positive reactions for revisit intention, since the analysis indicated that they would recommend the food in Penang Island to friends, and they are likely to revisit Penang Island for the good food and friendly people. Optimistically they would definitely come back to Penang Island for the food experience if they happened to be in Malaysia.

Quality made a contribution on revisit intention and it can be concluded that satisfaction will lead to revisit intention. Evidently, the positive relationship between higher levels of customer satisfaction and the intention to revisit or recommend a destination to others has been studied by previous authors. The researchers recommended that related tourism sectors and agencies in Malaysia to collaborate with the service providers (food preparer and travel agencies) in sustaining the cleanliness of food area, quality and value of food in order to entice more tourists to consume Penang's delicacies (Zainal et al., 2014; Atikahambar et al., 2014).

Apparently, when customers are satisfied with our services or products, it resulted in increased loyalty and future visitation. The results of this study are in line with previous researches, agreeing that satisfaction can lead to the revisit intention (Mostafavi et al., 2010; Gagic et al., 2013; Quach, 2013; Hendijani, 2016). Thus, this study contributes to more extensive understandings of theories that are can be applied to hospitalities and tourism industry in Penang Island. This study confirms the importance of quality of Penang food in enhancing the tourist satisfaction and revisit intention.

\section{CONCLUSION}

Beneficially this study is significant for the academician and the practitioners at large. It will assist marketers to enhance, improve and maintain factors that contribute to tourists' intention to revisit. Marketers should focus more on food quality to elevate the image of Penang Food as they are expanding the products and services and add differentiation to create exceptionality to attract tourists' attention. From the academic view, this research will be able to expand the portfolio information as well as expanding existing and new knowledge through research of food quality and tourists satisfaction; as well as sharing knowledge on the development of heritage food to promote a culture of research and analysis in exploring Malaysia's heritage food in line with the objectives of the Department of National Heritage.

Furthermore, the findings of this study also contribute to more extensive understandings of theories that can be applied to hospitality and tourism industry in Penang Island to sustain a position in the global industry as a food tourism destination preference. Notably, tourists' characters, attitudes and lifestyle have changed their tastes in encountering a particular tourism destination. Thus, these factors will influence a formation of tourist friendly destination concept, which will enable tourists to enjoy, and obtain in new knowledge and experience about tourism product such as food tourism.

Hence, to ensure the sustainability of food tourism in Malaysia and Penang food in particular, it is essential for state governments and tourism authorities as well as food operators to collaborate in the effort to survive the uniqueness of the local delicacies and food heritage. 


\section{LIMITATIONS AND RECOMMENDATION}

Due to time and budget constraints, this study specifically focused on food tourism in Penang. There was a lack of participation and cooperation from the international tourists due to the fact that this study does not offer them direct economic impact nor does it bring immediate profit to them, apart from language barrier among the tour guides and respondents. Future research could extent this study with other states such as Malacca and Kelantan which are known to have arrays of delicacies. It is also suggested that future studies should use the triangulation method to get further insights from food tourists regarding Malaysian delicacies. It is hoped that the findings from this study will serve as a guide for future research in shedding more lights to the food tourism in Penang.

\section{Acknowledgement}

We would like to express our sincere gratitude to all those who had participated and assisted us in this study. The authors declare that there is no conflict of interest.

\section{Corresponding Author}

Atikahambar Binti Yusni, Kulliyyah Hospitality \& Creative Arts, Universiti Islam Antarabangsa Sultan Abdul Halim Muadzam Shah (UniSHAMS), 09300 Kuala Ketil, Kedah Darul Aman, Malaysia.

Email: Atikahambar@unishams.edu.my

\section{References}

Abdelhamied, H. (2011). Customers' perceptions of floating restaurants in Egypt. Anatolia, 22:01, 115. doi:10.1080/13032917.2011.556212

Al-Tit, A. A. (2015). The effect of service and food quality on customer satisfaction and hence customer retention. Asian Social Science, 11(23), 129-139

A. Zainal, Y. Atikahambar, M. N. Mohd Hafiz, A.N. Zali \& M.Z. Kutut(2014).Examining Perceived Value and Satisfaction of Penang Delicacies in Predicting Tourists' Revisit Intention, Proceedings of 4 th International Conference on Global Business Environment (ICGBE-2014) 60

Allan, M. (2016). Exploring the relationship between local food consumption and intentional loyalty. Revista de turism-studii si cercetari in turism, (21), 33-38.

Altunel, M. C., \& Erkut, B. (2015). Cultural tourism in Istanbul: The mediation effect of tourist experience and satisfaction on the relationship between involvement and recommendation intention. Journal of Destination Marketing \& Management, 4, 213-221.

Bujisic, M., Hutchinson, J., \& Parsa, H. G. (2014). The Effects of Restaurant Quality Attributes on Customers Behavioural Intention, International Journal of Contemporary Hospitality Management, 26(8): 1270-1291, DOI 10.1108/ IJCHM-04-2013-0162

Canny, I. U. (2014). Measuring the mediating role of dining experience attributes on customer satisfaction and its impact on behavioral intentions of casual dining restaurant in Jakarta. International Journal of Innovation, Management and Technology, 5(1), 25-29 
INTERNATIONAL JOURNAL OF ACADEMIC RESEARCH IN BUSINESS AND SOCIAL SCIENCES

Vol. 8, No. 12, Dec, 2018, E-ISSN: 2222-6990 @ 2018 HRMARS

Chang, L. L. (2013). Influencing factors on creative tourists" revisiting intention: The roles of motivation, experience and perceived value (Doctoral dissertation, Clemson University).

Cho, H. S., Byun, B., \& Shin, S. (2014). An examination of the relationship between rural tourists" satisfaction, revisitation and information preferences: A Korean case study. Sustainability, 6(9), 6293-6311.

Economic Planning Unit (EPU) (2015). Eleventh Malaysia Plan 2016-2020 Anchoring growth on people. Kuala Lumpur. Retrieved from http:.//www.epu.gov.my

Gagić, S., Tešanović, D., \& Jovičić, A. (2013). The vital components of restaurant quality that affect guest satisfaction. Turizam, 17(4), 166-176.

Ha, J. Y. and Jang, S.C. 2010. Perceived values, satisfaction, and behavioral intentions: The role of familiarity in Korean restaurants. International Journal of Hospitality Management 29: 520-529.

Jayarman, K., Lin, S. K., Guat, C. L., \& Ong, W. L. (2010). Does Malaysian Tourism Attract Singaporeans to Revisit Malaysia? Journal of Business and Policy Research, 5(2), 159-179.

Jalis, M.H., Che, D., \& Markwell, K., (2014). Utilising local cuisine to market Malaysia as a tourist destination. 5 th Asia Euro Conference 2014. Procedia - Social and Behavioral Sciences, 144 ( 2014 ) 102- 110

Kim, Y. H., Kim, M., \& Goh, B.K., (2011). An examination of food tourist's behavior: Using the modified theory of reasoned action. International Journal of Tourism Management, 32(2011), 1159-1165.

Kostas Kapiris (2012)Food Quality, Hellenic Center for Marine Research(H.C.M.R.).Institute of Marine Biological Resource s(I.M.B.R.), Athens,Greece. https://www.scribd.com Accessed on 27 August 2017, pp1-144.

Lee, Cheng-Fei. 2015. Tourist Satisfaction with Factory Tour Experience. International Journal of Culture,Tourism and Hospitality Research, 9(3), 261-277

Li XR, Lai C, Harrill R, Kline S, Wang L (2011) When east meets west: An exploratory study on Chinese outbound tourists' travel expectations. Tourism Management 32(4), 741-749.

Majid, M. A. A., Alias, M. A. M., Samsudin, A., \& Chik, C. T. (2016). Assessing Customer-Based Brand Equity Ratings in Family Restaurant. Procedia Economics and Finance 37, 183 - 189. doi:10.1016/S2212-5671(16)30111-3.

Mostafavi Shirazi, S. F., \& Mat Som, A. P. (2010). Relationship Marketing and Community Involvement: Two Significant Factors for Tourism Strategies. In C.A. Brebbia \& F.D. Pineda (Eds.), Sustainable Tourism IV (pp. 47-53). Southampton, UK: WIT Press. http://dx.doi.org/10.2495/ST100051

Meladze, M. (2016). The importance of the role of local food in Georgian tourism. European Scientific Journal, ESJ, 11(10), 222-227

Mok O (2013) Penang turns to construction as manufacturing demands shrink [Online]. [Cited 2 October 2014].Available from: http://www.themalaymailonline.com/malaysia/article/penangturns-toconstruction-as-manufacturing-demands-shrink.

Mohammad, B. A. M. A. H., \& Som, A. P. M. (2010). An analysis of push and pull travel motivations of foreign tourists to Jordan. International Journal of Business and Management, 5(12), 41-50.

Nasir, A., Ahmed, M. A., Nazir, I., Zafar, H., \& Zahid, Z. (2014). Impact of different determinants on customer"s satisfaction level (A case of fast food restaurant). International Journal of Business and Management Invention, 3(9), 32-40. 
INTERNATIONAL JOURNAL OF ACADEMIC RESEARCH IN BUSINESS AND SOCIAL SCIENCES

Vol. 8, No. 12, Dec, 2018, E-ISSN: 2222-6990 @ 2018 HRMARS

Namin, A. (2017). Revisiting customers' perception of service quality in fast food restaurants. Journal of Retailing and Consumer Services 34 (2017) 70-81

Oliver, R. L. (1997). Effect of expectation and disconfirmation on post exposure evaluation: an alternative interpretation. Journal of Applied Psychology, 62(August), 480-486.

Prayag, G., Hosany., S, \& Odeh, K. (2013). The role of tourists' emotional experiences and satisfaction in understanding behavioral intentions. Journal of Destination Marketing \& Management, 2, 118-127

Penang Tourism Survey. (2016). Retrieved 7 March 2017, from https://www.researchgate.net/publication/316738046 Penang-Tourits Survey_2016

Penang State Tourism and Development,(2010). Practical Travel Guide Visit Penang 2010-2012. Practical Travel Guide Visit Penang 2010-2012,Retrieved March 14,2012, from http:www.visitpenang.gov.my

Petrick, J. F. (2002). Development of a multi-dimensional scale for measuring the perceived value of a service. Journal of Leisure Research, 34(2), 119e134.

Pham, L. T. M., Do, H. N., \& Phung, T. M. (2016a). The Effect of Authenticity Perceptions, Brand Equity on Brand Choice Intention: A Study in Ethnic Restaurants in Vietnam. Paper presented at the The 10th International Days of Statistics and Economics, Prague, September 8-10, 2016.

Pham, L. T. M., Do, H. N., \& Phung, T. M. (2016b). The Effect Of Brand Equity And Perceived Value On Customer Revisit Intention: A Study in Quick-Service Restaurants in Vietnam. Acta Oeconomica Pragensia, 24(5), 14 - 30. doi:10.18267/j.aop.555

Quach PG (2013). Examining international tourists' satisfaction with Hanoi tourism (Master's thesis). Available from: http://urn.fi/URN:NBN:fi:ula201306271236

Rajasenan, D., Varghese, M., \& Bijith, G. A. (2012). Tourist profiles and characteristics vis-à-vis market segmentation of ecotourism destinations in Kerala. Journal of Economics and Sustainable Development,3(14), 134-145.

Roozbeh Babolian Hendijani, (2016) "Effect of food experience on tourist satisfaction: the case of Indonesia", International Journal of Culture, Tourism and Hospitality Research, Vol. 10 Issue: 3, pp.272-282, https://doi.org/10.1108/IJCTHR-04-2015-0030

Rozekhi N A, Hussin S , Siddiqe A,P D Ab Rashid, Noor Salmi, (2016). The Influence of Food Quality on Customer Satisfaction in Fine Dining Restaurant: Case in Penang. International Academic Research Journal of Business and Technology.www.iarjournal.com Accessed on July 2017, pp 4550.

Ryu, K., Lee, H.-R., \& Kim, W. G. (2012). The influence of the quality of the physical environment, food, and service on restaurant image, customer perceived value, customer satisfaction, and behavioral intentions. International Journal of Contemporary Hospitality Management, 24(2), 200-223

Sabir, R. I., Ghafoor, O., Hafeez, I., Akhtar, N., \& Rehman, A. U. (2014). Factors affecting customer"s satisfaction in restaurants industry in Pakistan. International Review of Management and Business Research, 3(2), 869-876.

The Star (2014, Feb 4). Lonely Planet picks Penang as top spot for foodies in 2014. Retrieved from http://www.thestar.com.my/News/Nation/2014/02/04/Lonely-Planet Penang-food-top-spot/ 
INTERNATIONAL JOURNAL OF ACADEMIC RESEARCH IN BUSINESS AND SOCIAL SCIENCES

Vol. 8, No. 12, Dec, 2018, E-ISSN: 2222-6990 @ 2018 HRMARS

T. Ruxyn.( 2016). Penang Is The World's Best Food Destination Again!.Retrieved from https://www.malaymail.com/s/1163431/former-saveur-editor-says-penang-tops-the-list-asworld-food-destination

Tourism Malaysia (2015). Malaysia hotel guests by state 2013 [Online]. [Cited 12 April 2015]. Available from: http://corporate.tourism.gov.my/images/research/pdf/2013/hotel_guests/ Hotel_Guest_2013r.pdf.

Tourism Malaysia (2017). Tourism Performance Report January-December 2017 [Online]. Available from: https://www.tourism.gov.my/statistics

United Nation World Tourism Organization (UNWTO). 2017. "Second Global Report on Gastronomy Tourism, 2017 Edition". Available at http://cf.cdn.unwto.org/sites/all/files/pdf/gastronomy _report_web.pdf

Wang, C.-H., \& Chen, S.-C. (2012). The Relationship of Full-service Restaurant Attributes, Evaluative Factors and Behavioral Intention. International Journal of Organizational Innovation, 5(2), 248262

Y. Atikahambar, A. Zainal, Z. Ahmad Nizan, A. Nor'Aini \& M. K Zain (2014). Examining perceived value and tourists' satisfaction on Penang delicacies, Journal of Hospitality \& Tourism, 229-232. London: Taylor and Francis Group, ISBN 978-1-138-00151-0

Zabkar, V., Brenc, M. M., \& Dmitrovic, T. (2010). Modelling perceived quality, visitor satisfaction and behavioural intentions at the destination level. Tourism management, 31(4), 537-546. http://dx.doi.org/10.1016/j.tourman.2009.06.005

Zainal, A., Zali, A. N., \& Kassim, M. N. (2010). Malaysian gastronomy routes as a tourist destination. Journal of Tourism, Hospitality and Culinary Arts,1(2), 15-24 